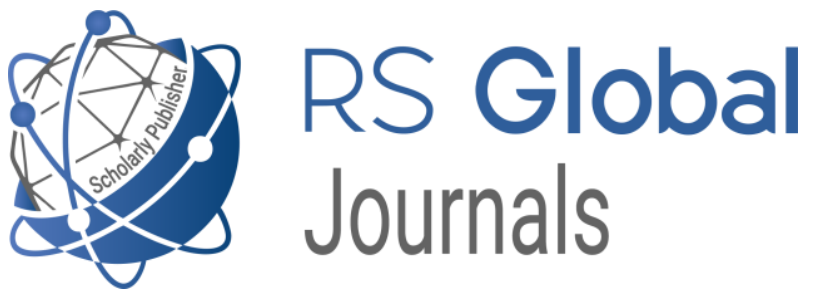

Scholarly Publisher

RS Global Sp. z O.O.

ISNI: 0000000484952390

Dolna 17, Warsaw, Poland 00-773

Tel: +48226022703

Email: editorial_office@rsglobal.pl

JOURNAL International Journal of Innovative Technologies in Social Science

p-ISSN $2544-9338$

e-ISSN

2544-9435

PUBLISHER

RS Global Sp. z O.O., Poland

ARTICLE TITLE

WAYS OF MODERNIZATION AND IMPROVEMENT OF ARCHITECTURAL EDUCATION IN UKRAINE

AUTHOR(S)

Kateryna Kapushchak, Nina Hnes, Yuliya Idak

Kateryna Kapushchak, Nina Hnes, Yuliya Idak. (2021) Ways of Modernization and Improvement of Architectural Education in

ARTICLE INFO Ukraine. International Journal of Innovative Technologies in Social Science. 1(29).

doi: 10.31435/rsglobal_ijitss/30032021/7489

DOI

https://doi.org/10.31435/rsglobal_ijitss/30032021/7489

RECEIVED

26 January 2021

ACCEPTED

17 March 2021

PUBLISHED

21 March 2021

LICENSE

This work is licensed under a Creative Commons Attribution

4.0 International License.

(C) The author(s) 2021. This publication is an open access article. 


\title{
WAYS OF MODERNIZATION AND IMPROVEMENT OF ARCHITECTURAL EDUCATION IN UKRAINE
}

\author{
Kateryna Kapushchak, Lviv Polytechnic National University, Ukraine \\ Nina Hnes, Lviv Polytechnic National University, Ukraine \\ Yuliya Idak, Dr. of Arch., Doc., Lviv Polytechnic National University, Ukraine, \\ ORCID ID: https://orcid.org/0000-0002-1123-5759
}

DOI: https://doi.org/10.31435/rsglobal_ijitss/30032021/7489

\section{ARTICLE INFO}

Received 26 January 2021

Accepted 17 March 2021

Published 21 March 2021

\section{KEYWORDS}

architectural education, the request of modern students, criteria for assessing higher educational institutions.

\begin{abstract}
The article identifies the problems faced by the Ukrainian architectural education and formulates the ways to overcome it. To formulate them, a survey was conducted among students studying abroad through the prism of comparing methodological approaches to the organization of the educational process and its content. The basic ones are those related to the practical component, technological equipment, the organization of the educational process and the relevance of the knowledge gained.
\end{abstract}

Citation: Kateryna Kapushchak, Nina Hnes, Yuliya Idak. (2021) Ways of Modernization and Improvement of Architectural Education in Ukraine. International Journal of Innovative Technologies in Social Science. 1(29). doi: 10.31435/rsglobal_ijitss/30032021/7489

Copyright: (C) 2021 Kateryna Kapushchak, Nina Hnes, Yuliya Idak. This is an open-access article distributed under the terms of the Creative Commons Attribution License (CC BY). The use, distribution or reproduction in other forums is permitted, provided the original author(s) or licensor are credited and that the original publication in this journal is cited, in accordance with accepted academic practice. No use, distribution or reproduction is permitted which does not comply with these terms.

Introduction. In recent years, the opportunities for obtaining education abroad for Ukrainian students have expanded significantly. International grants, scholarships for EU partner countries, the possibility of receiving free education in certain countries and prices for programs in others which so far differ little from paid education in Ukrainian universities - all these factors are taken into consideration by entrants today. International mobility policy has advanced significantly and continues to develop. As a result, the percentage of students interested in studying abroad increases every year. This means that if earlier the competition between educational institutions took place at the country level, now this issue arises at the international level. The architectural segment is no exception to all of the above. The issues of the need to improve architectural education, improving its quality has been covered for several years.

The purpose of the research word. To compare different approaches to the architectural educational process of Ukrainian and European universities and during the survey of students to determine which educational decisions cause a positive reaction, and which negative one for a better understanding of the needs and demands of modern entrants from architectural education. The phrase of Y. Goncharov and A. Kasych is very well-marked: "In the conditions of the knowledge economy, the one who skillfully uses them and turns them into income wins. That is why the world's attention to science is growing. «Expenditures on research and higher education are seen as investments in knowledge - a crucial factor in ensuring economic progress, enhancing professional creativity, improving living standards». [4, 42]. Hence the question whether Ukrainian students will invest in domestic architectural education in 10 years?

In September 2016, for funding the project «The Research Initiative on Democratic Reforms in Ukraine» (RIDRU, Ukraine-Canada), Kyiv International Institute of Sociology conducted a public opinion poll on attitudes towards education. The field stage lasted from 16 to 26 September 2016. The survey was conducted in 110 settlements (PSU) in all regions of Ukraine, except for the Autonomous Republic of Crimea. To the question «If you or your children or acquaintances chose where to continue their education after high school, what would you prefer?» $35 \%$ of young people chose the option of "university abroad". 
According to a social survey conducted in 2013 by GFK "Ukrainian Generation Z: values and guidelines" the following results were obtained:

Regarding higher education, a public opinion poll found that in the structure of violations of students' rights, the first place is occupied by violations of the right to receive quality education. $62 \%$ of respondents stated that educational services do not meet current standards, $60 \%$ - about the lack of logistical, financial and other support of the university, another $52 \%$ - about the impossibility or formal passage of internship.

According to sociological surveys conducted by CEDOS (Centre for Society Research) in 20162017 and the results of the Youth of Ukraine 2015 survey conducted by GfK Ukraine in 2015, more than 72,000 Ukrainians studied abroad, the vast majority of whom in European higher education institutions.

The most popular countries for Ukrainian entrants and students are Germany, Czech Republic, Bulgaria, Hungary, Italy, Spain, France, and Austria. Poland is currently the most popular choice among Ukrainian students. According to the CEDOS survey in 2015, at least 53,000 Ukrainians studied in Poland, one tenth of whom are engineering majors.

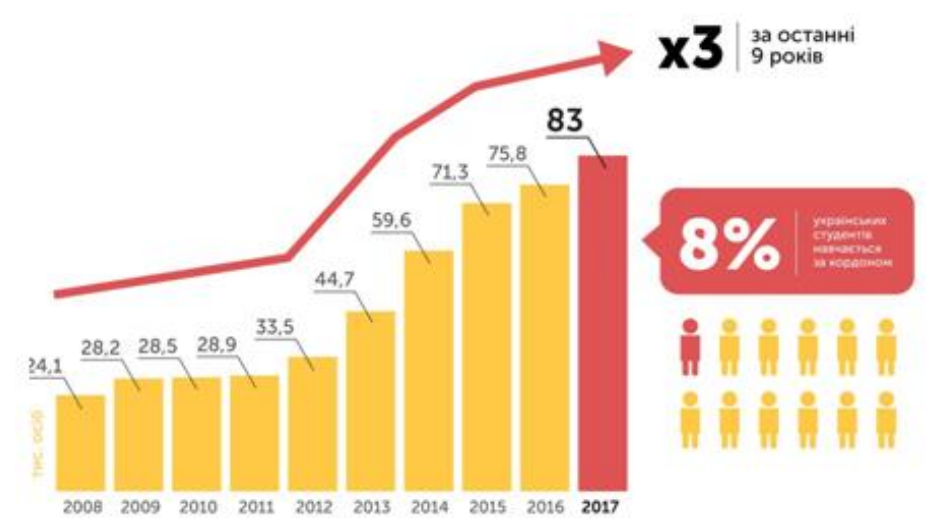

Fig. 1. Graph of growth in the number of Ukrainian students abroad (data and photo CEDOS): \% of Ukrainian students study abroad

If education abroad used to be expensive, now Ukrainian students have many opportunities. The international policy of integration of students from EU partner countries helps to make education abroad accessible to Ukrainian students.

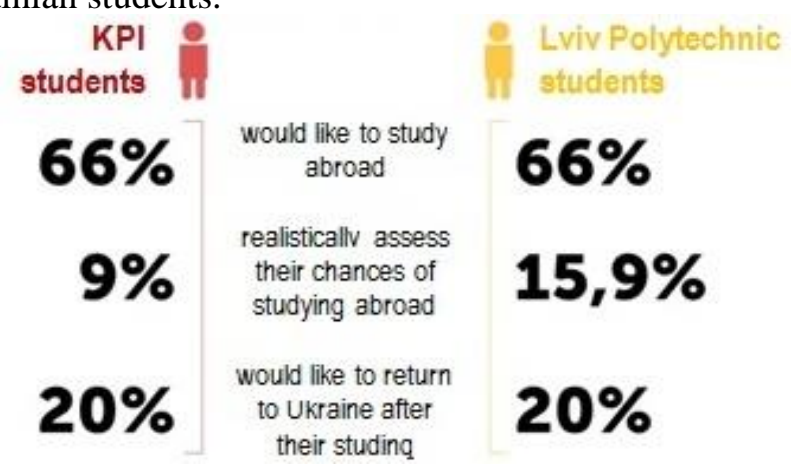

Fig. 2. Survey of students of KPI and Lviv Polytechnic (Photo: IECDR

The growing pace of international academic exchanges may form a negative component in the overall perspective for our country. It lies in the fact that a significant percentage of Ukrainian citizens, especially young people studying abroad, in particular in European universities, may not return to Ukraine and accelerate the pace of labour migration. To avoid the outflow of young future professionals abroad, there is a need to assess the state of domestic education, in this case architectural one, and determine what adjustments need to be made.

Analysis of publications on the selected problem. Focusing on the problems of architectural education, I. V. Birillo in her article Modern Problems of Architecture and Urban Planning has stressed: «Modern education is characterized by the need for constant innovations, updates, adequate to the current stage of development of society».

It was revealed that the informative training of future architects in the higher education system does not meet the requirements of today, in addition, it does not provide the social order of society for the near future in connection with the all-encompassing informatization. 
The formed discrepancy between the incorrectly created model of a modern specialist and the real requirements of employers to them has led to the incompetence of specialists in the workplace.

The problem of conformity of professional training of specialists to the modern needs of architectural design in the conditions of modern integrated information processes and the requirements of employers has been relevant and timely. Analysis of Educational and qualification characteristics (EQC), Educational and professional programs (EPP) shows that during training and job instructions the student receives theoretical and practical knowledge that will allow them to take a number of positions in the field of architecture.

However, the results of the study of professional activities in educational institutions of graduates of the architectural profile and student trainees indicate that

- they are not prepared for production processes;

- do not know modern information technology;

- cannot make effective decisions on their own;

- do not always show a creative approach to solving professional problems;

- spend a lot of time on project tasks.

All this complicates the process of their adaptation in institutions, exacerbates the problems of professional and social development.

An important point was voiced in the article «Reforming Architectural Education», where it is noted that the world and domestic experience of modern architecture testifies that a single informatization process in architecture develops along two parallel directions: the first one is technological design, significantly intensifies and changes its procedural content. The second one is the research conducted in a virtual environment (or virtual research), that activates the designer's creativity potential of the designer and forms the professional language of a modern architect.

Domestic practice of higher architectural education is developing mainly in the first direction the spontaneous introduction of digital technologies through the study of computer software packages. This satisfies, first of all, the demand of the architectural and construction market for a specialist who owns the craft that is needed to maintain of project documentation in electronic form. However, this specialization does not serve the development of the artistic component of the architectural profession. Birillo, in her article "Computer training of future architects" defines 3 main points for which the quality of training of future architects at the university will meet the demands of society:

- the content of education will include modern general-purpose ICT and information technologies of architectural design, and modern computer tools (technical, communication, software) of the architect's professional activity will be used in the educational process;

- the educational process will organically combine traditional and computer-oriented methods, comprehensive use of printed and electronic media, traditional and information and communication tools;

- to increase the practical orientation of training and the level of architectural and design

Having analyzed the sources published within the last ten years, it is possible to clearly describe the problems identified in the organization and planning of the educational process in architectural higher educational institutions of Ukraine. As of 2020, they are still relevant. And if before their relevance was in the poor-quality training of future qualified personnel, today in the current situation it is possible to add the threat of labour migration caused by the search for quality education.

Research results. To achieve a better understanding of the problematic points in the architectural educational process, and awareness of the needs of modern students from the education of the architectural segment, the study of this work compares the methodological approaches of variable higher education institutions. Architectural universities from five different countries within Europe were selected to compare the methodologies of the educational process, as well as one of the Ukrainian universities. The main criterion for the study was the opinion of students. Citizens of Ukraine and Europe were invited for the survey.

To counterbalance, there were students from both conservative universities (Ukraine, Spain) and progressive (Germany, Portugal, Sweden, Belgium) among the respondents.

As part of the study, students were asked questions regarding the content of both the general organizational plan and the question of specifically selected educational programs.

The survey identified the main aspects for comparison. They are as follows:

- the practical component of the educational process;

- technological equipment and its role in the educational process;

- organization of the educational process; 
a) Practical work in classes;

b) Organization of a lecture course;

c) Relevance of the knowledge gained;d) General organization.

- the most common problems in the educational architectural process;

- difference between studying architecture in Ukraine and Europe.

1. The practical component is an integral aspect of the educational process in the architectural trend. The search for practical application of skills was not found to be a critical problem in the opinion of one of the respondents, both Ukrainian and European universities.

The following possibilities were especially highlighted in: cooperation of the university with architectural companies and their internship offers to students involvement of practicing specialists outside the university (master classes); familiarizing students with the specifics of the work of architectural companies and their areas of activity (excursions, tours), holding an open day by representatives of architectural organizations for students of a particular educational institution.

2. Another topical and at the same time controversial issue is the technological equipment of laboratories / studios of educational institutions and their impact on the architectural educational process. Concerning this question, it is widely believed among the respondents that more expensive technical equipment does not affect, or only partially affects the education of architects, because it does not guarantee the expansion of knowledge and development of the student. "It is possible to study without innovative technologies, but in this case it is necessary to focus on the organization and theoretical approach to the educational process" - O. Tykhonova, Master's degree from NULP, and doctoral degree from the University of Lisbon. Such survey results can be considered positive, as they show that there is no direct relationship between the student's qualifications and the equipment of the laboratories in which they works. Nonetheless, the availability of innovative equipment, although not a basic necessity, has a positive impact on the overall learning process, and obviously raises the rating of the educational institution: «Equipment saves time and energy, reduces errors, provides new opportunities for modeling that are difficult to perform manually» - O. Tykhonova. An example of effective modern equipment of the respondent's university is dot matrix and laser 3D printers, VR design.

3. The general organization of the educational process needs special attention. To analyze this issue better, let's divide it into subsections.

Practical work in classes. Students of conservative universities shared negative feedback. Among the highlighted disadvantages: inconsistency of design works with the real requirements of our time, outdated approach to teaching, disorganized use of time during classes. The lack of a design process using modern computer tools, or only a superficial familiarizing with the software package; providing paid computer technology courses, which makes it difficult for students to access them; propaganda of manual execution of design processes, which has lost its relevance were found ineffective. Positive feedback received progressive educational institutions that implement active work of students and their education in relevant and innovative computer architectural programs; apply design solutions relevant to modern problems.

Organization of a lecture course. Respondents recognized the conduct of a lecture course in the format of dictation and copying of literature as unsatisfactory. Students considered such theoretical classes as ineffective use of time. Access to the library and the Internet eliminates the need to dictaterewrite the material, a method that was introduced before the development of information accessibility.

Positive feedback was expressed on European universities, where the system of submission of theoretical material is better focused on learning - all the necessary literature is provided by the university in online access. Students have the opportunity to prepare for the lesson in advance, after which they participate in the lesson in panel discussions and discussions of the material with classmates and the teacher. This approach promotes the assimilation of knowledge, therefore, the approach to theoretical training is effective.

Positive feedback was received from students of progressive European universities, where the program is updated and remains flexible in relation to the demands of society, the content of lecture courses changes according to the latest trends, the design course keeps pace with the development of innovative methods. "With the current situation of quarantine, life has changed dramatically, therefore, new requirements for urban planning have appeared. We create spaces that meet these new requirements in the design course" - O. Khabaylyuk, Bachelor of IFNTUOG, Master's degree from Bauhaus-Universität Weimar. The respondent replied that the curriculum of his university provides knowledge that is and will be relevant in the near future, and certain design methods that are taught in 
practical classes have not yet become widespread due to their novelty. BIM design application, generative and parametric design are actively used.

General organization of training. Ukrainian architectural education is still at a developmental stage. It is undergoing slow adjustments, and many more changes need to take place for the curriculum to meet students' expectations. Next, I want to point out the features of the organization of some European universities, in the opinion of the respondents, especially influenced the effectiveness of their education:

- a common application of group work - unlike individual ones, joint projects teach cooperation, joint search for a problem solution, and search for compromise solutions;

- the ability to choose subjects independently in accordance with their interests - in most cases, the program consists of at least $50 \%$ of elective subjects;

- the opportunity to take a course or part of a course at partner universities with the transfer of credits (University of Lisbon);

- division of semesters into chronological periods in accordance with the implementation of projects (Malmo University, Sweden) - projects are carried out in order, and not simultaneously, reducing the level of stress and excluding defocusing on different tasks\$

- the presence of scientific activity and the creation of publications at a mandatory level - "It is definitely important to be able to reasonably express one's thoughts" - O. Savchuk, Master's degree from KU Leuven, Belgium);

- common practice of workshops;

- tours to modern and historical architectural sites for students;

- organized meetings with famous figures in architecture - «It is important and very inspiring to meet popular people in the field you are studying. Thanks to this opportunity, I was lucky to meet Norman Foster» (Paula Munoz, Master's degree from of the Polytechnic University of Madrid).

4. The respondents were asked which aspects in the architectural educational process they identify as problematic. As a result, the following answers were received:

- absence or lack of practice;

- defocused attention in the process of studying subjects not in the field of architecture in the process of studying subjects not from the field of architecture;

- uncertainty and unclear organization of educational structures;

- inflexibility and immutability of the program, lack of innovation;

- creation of projects, without taking into account real conditions and restrictions;

- lack of opportunity to form the curriculum yourself;

- lack of freedom to make design decisions;

- lack of support for student creativity.

5. What influences the effectiveness of studying architecture, according to students? The answers of the respondents agreed as follows:

- balance between the study of theory and practical application;

- critical thinking;

- practical experience of teachers;

- communication with consumers, social component of design.

The first point is the most common answer among respondents.

Also, after analyzing the students' answers, it was revealed, that teachers in progressive institutions have better relationships with students than in conservative institutions. At a time when the last ones prioritize the compliance with traditional norms and restrictions in the process of work, in progressive institutions the development of creative thinking and freedom of decision-making are in priority.

6. Those students, whose educational experience includes both Ukrainian and European universities, were asked the question, what is the difference between domestic education and foreign one.

Answers received: - «The Ukrainian system lacks critical thinking. There are such things as subjectivity, emotionality and impulsiveness there. There are generally no such phenomena in Europe, there is objective argumentation with references to sources confirming the teacher's opinion there. «The program is well formed in Ukrainian universities but the problem lies in the content and presentation of material»-O. Khabayluk.

«The theoretical basis I received in Ukraine was satisfactory at the time of my studies, but there was a lack of a technological component in it. Also unsatisfactory is the fact that it was impossible to choose the program (selective subjects); - O. Tyhonova.

«Critical thinking and loyalty from teachers is what I met in Europe and what was lacking in the Ukrainian university. A sense of security and trust in the teacher is important in the educational 
process. Architectural education needs the possibility of radical change, but it is difficult to implement with a centralized system in Ukraine»-O. Savchuk.

Summing up the results of the analysis of the survey of respondents, we can clearly see 2 lines of opposition. The first one is different approaches to architectural education - conservatism and progressiveness, and completely different reaction of respondents to these methods. The study showed that conservative education received much more negative feedback and the students surveyed were significantly less satisfied with the chosen program than students who chose the program of a progressive architecture university. This can be justified by the fact that the traditional approach is less adapted to making changes, the progressive on as opposed to, aimed at tracking and implementing them. The organization of education of Ukrainian and European conservative higher education institutions has common features, and the feedback on universities was quite similar. This dispels the assertion that studying abroad can always fulfill a student's needs. However, it does not negate the fact that there are a large number of institutions with a non-conservative approach that satisfy applicants.

The second line of opposition is education at a Ukrainian university and study abroad. In addition to the difference between the methodological approaches to teaching, there are a number of controversial issues in Ukrainian education that require more attention, adjustment and more targeting to fulfill student requests. It is problematic that some aspects remain unchanged for decades, and it is their presence that leads to the graduate of unskilled specialists and pushes them to choose: to give preference to foreign progressive universities, or to expect the probability of changing the domestic program.

Conclusions. What does this ultimately lead to? And what, at the very least, is needed to make architectural education in Ukraine more efficient and attractive for applicants?

1. From standards to progress. Instead of focusing on whether certain standards are being met in the educational process, students' progress should be monitored. The main priority in the curriculum is often the passage of the subject, rather than mastering the material, which basically neutralizes the acquisition of knowledge.

2. From compulsion to interest. On the negative side, most architecture programs are standard and do not include a selection of subjects. The result is that students take courses in subjects that may be outside their range of interests. In this situation, students are forced to study, but compulsion should not be the basis of the curriculum. By giving the opportunity to choose at least $50 \%$ of subjects, there will be created conditions in which students will form their own program in accordance with their interests, receiving a greater incentive for learning. Orientation to the interests of students is the key task of the educational institution.

3. From lectures to practical experience. Gaining knowledge by listening and copying is a passive method of assimilating information, which is the least effective, because it does not include timely feedback. The format of the lecture process itself is the minimum that needs to be changed is. Audience communication, surveys, interactive, discussions - the introduction of these adjustments can increase the efficiency of assimilation of the of the submitted materia. But of course, you can't do without practice. Some training courses basically do not contain practical experience, in fact, they do not reinforce the knowledge gained and level the.

4. From professors to mentors. The practical experience of the teacher is extremely important and becoming a practicing architect is possible only by learning from those who personally have experience in the design process. These people know how architecture is created in life, they know the trends and the methods are less or more popular. Becoming an architect is worth learning from those who have already passed this path.

5. From traditions to relevance. Traditional methods are not always relevant today, and after a few years may not be at all inherent in the design process. Architecture is one of the fastest growing industries where new trends appear every year. The relevance and novelty of methods of architectural design is a basic criterion of modern education and one of the key demands of society.

Table 1. The latest approaches to the implementation of architectural education

\begin{tabular}{ccc}
\hline Standards & $\rightarrow$ & Progress \\
\hline Compulsion & $\rightarrow$ & Interest \\
\hline Lectures & $\rightarrow$ & Experience through practice \\
\hline Professors & $\rightarrow$ & Mentors \\
\hline Traditions & $\rightarrow$ & Relevance \\
\hline
\end{tabular}


The education of architects is only a part of the entire educational system in Ukraine, which, unfortunately, needs fundamental reforms. However, the need for these changes today is very urgent. After all, there are many more opportunities for students and their parents now than a few years ago. Student feedback is one of the most important criteria for evaluating a higher education institution. By listening to the needs of today's youth, you can find not only answers to many questions, but also find their solutions. Ignoring and postponing problems will lead to choices over and over again: architectural education in Ukraine or abroad?

Interviewed respondents: O. Khabaylyuk - Bachelor of IFNTUOG, Master's degree from Bauhaus, Germany; O. Tykhonova, Master's degree from NULP, doctoral degree from the University of Lisbon, Portugal; Paula Munoz, Master's degree from the Polytechnic University of Madrid, Spain; Oksana Savchuk, Master's degree from the Malmo University, Sweden, Master's degree from the KU Leuven, Belgium; Maryna Peleshchak, Master's degree from NULP.

\section{REFERENCES}

1. Vakhovych, I., M., Ishchuk, L., I. and Pyrig, S., A., 2014. State and Problems of Higher Education in Ukraine [Stan i problemy vyschoyi osvity v Ukrayini]. Economics and management of the national economy [Ekonomika ta upravlinnya natsionalnym hospodarstvom], p. 63-69.

2. Khan, E., 2018. Ukrainian students in the higher educational establishments of the European Union: problems and prospects of international academic exchanges [Ukrayinski student u vyschyh navchalnyh zakladah Yevropeyskoho Soyuzu: problem ta perspektyvy mizhnarodnyh akademichnyh obminiv]. European Historical Studies [Yevropeyski istorychni studiyi], 11, p. 79-98.

3. The Research Initiative on Democratic Reforms in Ukraine (RIDRU). [Electronic resource]. - Mode of Access: http://ridru.artsrn.ualberta.ca/ Last signon: 19.01.2021.

4. CEDOS. [Electronic resource]. - Mode of Access: https://www.cedos.org.ua/ Last signon: 19.01.2021.

5. Birillo, I., V., 2015. Modern requirements for the training of future architects [Suchasni vymohy do pidhotovky maybutnih arhitektoriv]. Modern problems of architecture and urban planning [Suchasni problemy arhitektury la mistobuduvannya], 40, p. 349-356.

6. Birillo, I., V., 2015. The Reform of Architectural Education [Reformuvannya arhitekturnoyi osvity]. [Electronic resource]. - Mode of Access: https://ccjournals.eu/ojs/index.php/fund/article/download/194/184/ Last signon: 19.01.2021.

7. Birillo, I., V., 2015. Computer training of future architects [Informatychna pidhotovka maybutnih arhitektoriv]. Scientific notes. Series Problems of methods of physical-mathematical and technological education [Naukovi zapysky. Seriya Problemy metodyky fizyko-matematychnoyi i tehnolohichnoyi osvity], 4 (1), p. 11-16 [Electronic resource]. - Mode of Access: https://core.ac.uk/download/pdf/228637461.pdf Last signon: 19.01.2021.

8. Habrel, M. and Kaydanovska, O., 2017. The problems of professional architects training: relational work [Profesionalizatsiya $\mathrm{v}$ arhitekturniy osviti: problem pidhotovky arhitektoriv do profesiynoyi diyalnosti]. Ukrainian professional education [Ukrayinska profesiyna osvita], 1, p. 38-51.

9. QS World University Rankings. [Electronic resource]. - Mode of Access: https://www.topuniversities.com/qs-world-university-rankings Last signon: 19.01.2021. 